\title{
SYNTHESIS, CHARACTERIZATION AND ANTIMICROBIAL ACTIVITY OF MANGANESE(II) AND NICKEL(II) COMPLEXES OF 7- DIETHYLAMINOBENZYL-8-HYDROXYQUINOLINE
}

\author{
C.Muthukumar ${ }^{*}$, A.Sabastiyan ${ }^{b}$, S.Valarselvan ${ }^{c}$, M.Subramanian $^{c}$, M.Shanmugavadivel $^{\mathrm{c}}$ \\ ${ }^{*}$ Dept.of Chemistry,J.J.College of Arts and Science(Autonomous), Pudukkottai-622 422 \\ cmkumar72@gmail.com \\ ${ }^{\mathrm{b}}$ Dept.of Chemistry,Shivani Engineering College, Tiruchirappalli-620 009 \\ 'Dept.of Chemistry,H.H.The Rajh's College, Pudukkottai - 622001
}

\begin{abstract}
8-Hydroxyquninoline Mannich base namely 7-diethylaminobenzyl-8-hydroxyqunioline(DEBQ) was synthesized and characterized by elemental analysis and spectral studies. Chelates of DEBQ with manganese(II) and nickel(II) were isolated and structurally characterized by elemental analysis, electrical conductance, magnetic susceptibility measurement, thermal analysis, IR,UV-Vis, EPR and Mass spectral data. The Mannich base ligand is bidentate and chelates through the phenolic oxygen and the aliphatic tertiary amino nitrogen atoms. Based on the magnetic and electronic spectral data all the $\mathrm{Mn}^{\prime \prime}$ complexes are assigned an octahedral geometry and $\mathrm{Ni}^{11}$ complexes are assigned a tetrahedral geometry. Antimicrobial susceptibility screening of the Mannich base shows that it possesses excellent activity when compared to the standard drugs and the metal complexes studied. Among the chelates, $\mathrm{Mn}^{\text {" }}$ chelate is more potent than $\mathrm{Ni}^{\mathrm{Il}}$ chelate. Thermal analysis of a few compounds shows two stage decomposition patterns.
\end{abstract}

msninfonet@gmail.com

Keywords: 8-Hydroxyquinoline, Mannich base, Thermal decomposition, Antimicrobial screening, Metal chelates.

\section{Council for Innovative Research}

Peer Review Research Publishing System

Journal: Journal of Advances in Chemistry

Vol.12, No. 4

www.cirworld.com, editor@cirworld.com 


\section{Introduction}

Synthetic chemists and pharmacologists show much interest in heterocyclic compounds containing quinoline moiety because of their unique chemical and pharmacological properties (Balasubramanium M and Keay, JG, 1996; Micheal IP, 1997; Maguire M P et al, 1994).Quinoline derivatives exhibit versatile pharmacological properties(Vetrivel Nadaraj et al, 2006; Pandey V.K and Menal Tondan, 2001; Yuki Sowda et al., 2004; Brain D Lee et al 2004; Singh O MV and Muthukrishnan M, 2001; Guytan A C and Hall JE, 1998; Rao A et al, 2002; Meth-Cohn et al., 1981) such as antiinflammatory, antibacterial, antifungal, antiallergic, antidepressant, antiasthmatic, antimalarial, antiviral, antitumour, neuroleptic, antihypertensive, cytotoxic, hypnotic, sedative,bronchodilator etc activities.8-Hydroxyquinoline is toxic if injected directly but its derivatives are useful as medicine in view of their biological activities . 8-Hydroxyquinoline is much useful in analytical chemistry also due to its chelating ability(Bassett $J$ et al, 2000). When 8-hydroxyquinoline is subjected to Mannich condensation with aldehydes and secondary amines it yields Mannich bases which could display more potent pharmacological properties and also stronger chelating tendencies. Mannich base coordination chemistry has been a popular area of research due to the diverse range of biological, analytical and industrial applications of the Mannich base metal chelates (Sathya et al, 2012; Muthukumar C et al, 2012; Ramesh M and Sabastiyan A,2012, Sabastiyan A and Yosuva Suvaikin M,2012). Hence in this work, $\mathrm{Mn}^{\|}$and $\mathrm{Ni}^{\|}$chelates of 7-diethylaminobenzyl-8-hydroxyquinoline(DEBQ) have been synthesized, characterized and their antimicrobial potency screened against a few pathogenic microorganisms.

\section{Experimental}

\section{Materials and Methods}

All the chemicals and solvents used were AR grade products. The microelemental analyses were performed using Carlo Erba $1108 \mathrm{CHN}$ analyzer. Metals and anions were estimated by conventional wet chemical analyses. Molar conductivities were measured in $\sim 10^{-3} \mathrm{M}$ DMF solutions at room temperature using Systronics Conductivity Meter 304. FT-IR Spectral measurements were made with Perkin - Elmer Spectrum - $1 \mathrm{FT}$-IR Spectrometer as $\mathrm{KBr}$ pellets. Mass spectra were recorded using JEOL D-300 (EI) Mass Spectrometer. ${ }^{1} \mathrm{H}$ NMR and ${ }^{13} \mathrm{C}$ NMR spectra were recorded on JEOL GSX-400 FT NMR Spectrometer (400 MHz) employing TMS as internal reference and DMSO- $\mathrm{d}_{6}$ as solvent. Electronic absorption spectra were measured in DMF solutions using Perkin - Elmer EZ301 Spectrophotometer. Magnetic susceptibility measurements were made on a Gouy magnetic balance at room temperature using $\mathrm{Hg}\left[\mathrm{Co}(\mathrm{SCN})_{4}\right]$ as calibrant. Simultaneous TG/DTA/DTG thermograms were recorded in the admosphere of air on a Perkin-Elmer Thermal analyzer.

\section{Synthesis of 7-diethylaminobenzyl-8-hydroxyquinoline(DEBQ)}

The Mannich base (DEBQ) was synthesized (Tromontini,1973; Tromontini M and Angiolini L,1994)by interacting 8hydroxyquinoline $(14.51 \mathrm{~g}, 0.1 \mathrm{~mole})$ with benzaldehyde $(10.6 \mathrm{~g}, 0.1 \mathrm{~mole})$ and diethylamine $(7.31 \mathrm{~g}, 0.1 \mathrm{~mole})$ in acetone medium at room temperature. The brownish-yellow solid compound formed was filtered and purified by recrystallization in ethanol (Yield $~ 70 \%$, melting point : $63-64^{\circ} \mathrm{C}$ ). DEBQ is systematically named as 7-diethylamino(phenyl)methylquinolin8-ol. The synthesis and characterization of this Mannich base has been already reported by us(Muthukumar C et al,2013).

\section{Preparation of $\mathrm{Mn}^{\mathrm{II}}$ and $\mathrm{Ni}$ " complexes of DEBQ}

The $\mathrm{Mn}^{\prime \prime}$ and $\mathrm{Ni}^{\prime \prime}$ complexes were isolated by interacting the respective hydrated metal salt $(0.01$ mole) with the ligand $\operatorname{DEBQ}(0.01 \mathrm{~mole})$ in hot ethanolic medium. The precipitated metal complexes were filtered, washed with ethanol and dried in a hot air oven at $\sim 70^{\circ} \mathrm{C}$.

\section{Invitro antimicrobial screening}

Antimicrobial screening of the organic ligand and its metal complexes was carried out by agar well diffusion technique (Cruickshankt R,1975). S.aureus and E.coli were the bacterial strains and P.Chrysogenum and A.niger were the fungal species employed. The concentrations of test samples in DMSO solutions were 50 and $100 \mu \mathrm{g} / \mathrm{mL}$. Antimicrobial activities of samples were determined by measuring the diameters of zones of inhibition $(\mathrm{mm})$ in Muller Hinton agar medium after 24 hours of incubation for bacterial species and after 48 hours of incubation for fungal species. All the experiments were performed in triplicate. Growth inhibition produced by a particular sample was compared with that of the standard bacterial drug ampicillin and that of standard fungal drug amphotericin-B.

\section{Results and discussion}

\section{Structural characterization of DEBQ}

Elemental composition Calculated for $\mathrm{C}_{2} \mathrm{H}_{22} \mathrm{~N}_{2} \mathrm{O}$ : C 78.43; H 7.189; N 9.15\% Found C 78.44; H 7.20; N 9.16\%. FT-IR absorption frequencies $\left(\mathrm{cm}^{-1}\right.$ in $\left.\mathrm{KBr}\right): 3392 \mathrm{~V}_{\mathrm{OH}} ; 3049,3100 \mathrm{~V}_{\mathrm{CH}} ; 1579,1471-1409 \mathrm{v}_{\mathrm{C}=\mathrm{C}}$ and $\mathrm{v}_{\mathrm{C}=\mathrm{N}}$ aromatic; $1379 \mathrm{~V}_{\mathrm{CN}}$ $1093 v_{C O} ; 1284-1275 v_{C N C}$.UV - Vis data ( $\lambda$ in nm, in DMF): $316 \mathrm{n}-\pi^{*} ; 260 \pi-\pi^{*} .{ }^{1} \mathrm{H}$ NMR chemical shifts $(\delta$ in ppm) : 7.2 - 8.2 pyridine ring protons; $6.9-7.2$ benzene ring protons, 6.4 benzylic proton; $2.2 \mathrm{~N}\left(\mathrm{CH}_{2}\right)_{2}$ protons; $1.3 \mathrm{CH}_{3}$ protons, $6.6 \mathrm{OH}$ proton. ${ }^{13} \mathrm{C}$ NMR chemical shifts $(\delta$ in ppm) : $137.6,127.6$ bridgehead carbons in quinoline moiety; $126.3-129.3$ other aromatic carbons,71.3 benzylic carbon;45 $\mathrm{N}\left(\mathrm{CH}_{2}\right)_{2}$ carbons;148.1 carbon with $\mathrm{OH}$ group. Mass spectral data : molecular ion $(\mathrm{m} / \mathrm{z}): 306$. The structural characteristics of DEBQ have been communicated by us(Muthukumar $C$ et al,2013). 
Based on these physico-chemical data, the structure of DEBQ is confirmed as given in Figure 1.<smiles>CCN(CC)C(c1ccccc1)c1ccc2cccnc2c1O</smiles>

Figure 1 Chemical structure of DEBQ

\section{Structural characterization of metal complexes}

The analytical and conductivity data of the metal complexes of DEBQ are provided in Table1. These data indicate that the isolated metal complexes have 1:1 stoichiometry and are non-ionic in behaviour (Greay WJ, 1971). Further, the mass spectrum of the $\mathrm{Ni}^{\mathrm{ll}}$ sulphato complex(Fig.2) registers the molecular ion peak at 461 , which indicates 1:1 stoichiometry for the same. The non-electrolytic behaviour of metal complexes suggests the bonding of anions to the respective metal ion in the complex species.

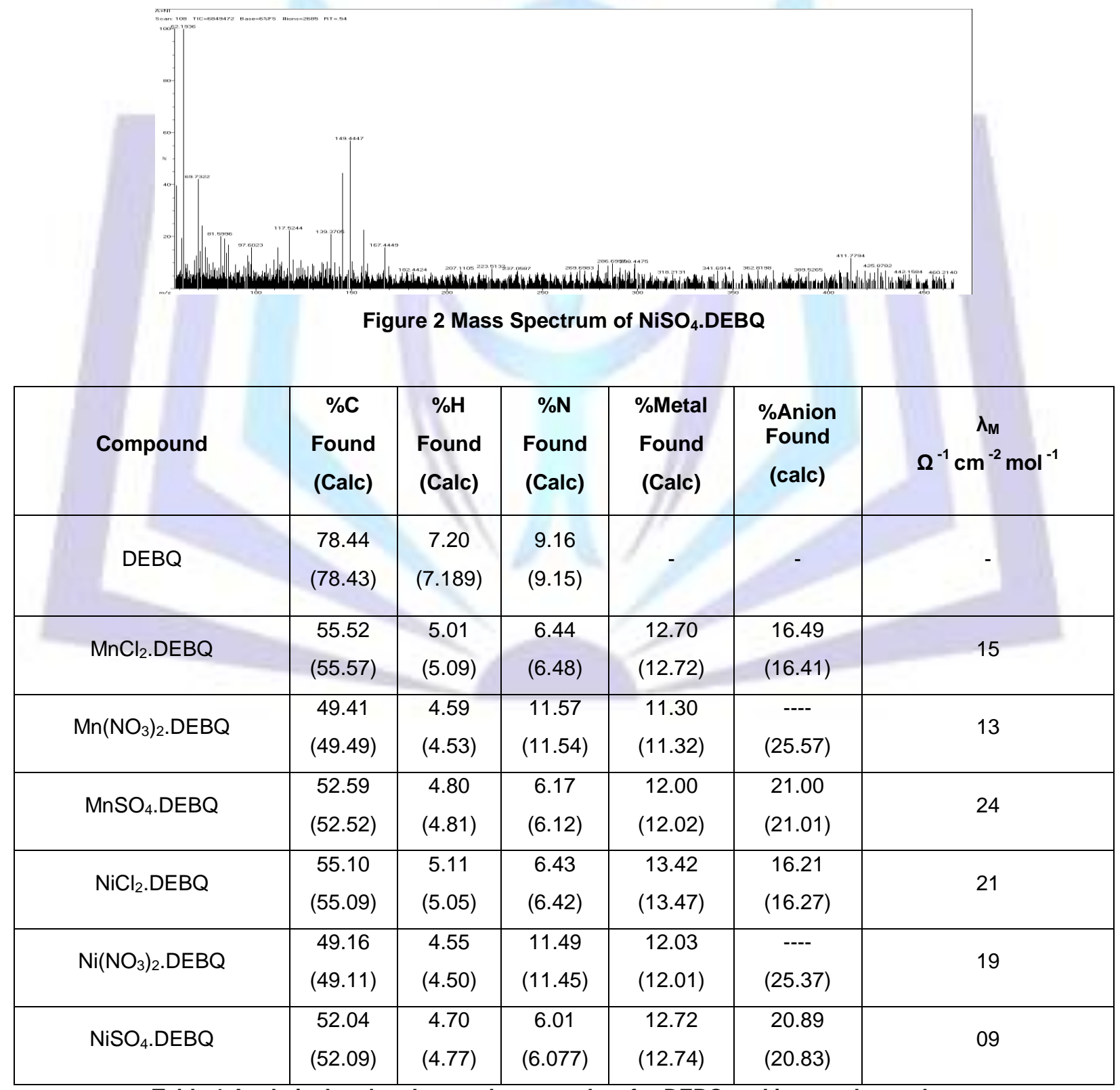

Table 1 Analytical and molar conductance data for DEBQ and its metal complexes 


\section{Infrared spectral studies}

The relevant IR absorption frequencies recorded for the ligand DEBQ and its metal complexes (Silverstein RM and Webster FX,1997; Nakamoto K,1978; Tamilvendan D et al,2010; Ferraro JR.1971) are provided in Table 2.A broad absorption at $3392 \mathrm{~cm}^{-1}$ is attributed to the presence of a phenolic $\mathrm{OH}$ group in the quinoline moiety of the organic ligand. In the vibrational spectra of the $\mathrm{Mn}^{11}$ and $\mathrm{Ni}^{11}$ metal complexes, this band appears split and shifted to $3383-3326 \mathrm{~cm}^{-1}$ region predicting the coordination of the phenolic oxygen atom to the metal ion. Normally when an aqueous solution of a 8 hydroxyquinoline derivative is added to an aqueous solution of the metal salt, the quinoline $\mathrm{N}$ and ionized phenolate $\mathrm{O}$ chelate to the metal ion to precipitate the coordination compound. But in the precent study, the complex preparation was attempted in an ethanolic medium and the ionization of the phenolic $\mathrm{OH}$ in to $\mathrm{O}^{-}$was not possible.Also the presence of anionic groups such as $\mathrm{Cl}^{-}, \mathrm{NO}_{3}{ }^{-}$and $\mathrm{SO}_{4}{ }^{2-}$ in the complex species excludes the existence of phenolate anion in the coordination compounds. Further the pyridine ring vibrations which are usually observed at about $604 \mathrm{~cm}^{-1}$ (inplane ring deformation) and $405 \mathrm{~cm}^{-1}$ (out of plane ring deformation) have not shifted to high frequencies in the spectra of the complexes indicating non -involvement of the pyridine ring nitrogen atom in coordination

The ligand absorption bands observed at $1284-1275 \mathrm{~cm}^{-1}$ are ascribed to the $\mathrm{C}-\mathrm{N}-\mathrm{C}$ stretching vibrations of the diethylamino moiety. But in the IR spectra of the metal complexes, these vibrations have shifted to a lower region of 1273 $1208 \mathrm{~cm}^{-1}$ pointing to the bonding of the aliphatic tertiary amino nitrogen atom to the metal ion. The coordination of a tertiary amino nitrogen is not sterically favourable, but the possibility of chelation tends to its coordination to a metal ion. Further the existence of new non-ligand bands in the regions $606-529 \mathrm{~cm}^{-1}$ and $526-420 \mathrm{~cm}^{-1}$ which indicate $\mathrm{v}_{\mathrm{MO}}$ and $\mathrm{V}_{\mathrm{MN}}$ vibrations respectively also predict the bidentate coordination of the Mannich base ligand through the phenolic $\mathrm{OH}$ group and the diethylamino nitrogen atoms. The nitrato groups in $\mathrm{Mn}^{11}$ complex exhibit vibrations at $1575\left(\mathrm{~V}_{5}\right), 1371\left(\mathrm{~V}_{1}\right)$ and $1031 \mathrm{~cm}^{-1}\left(v_{2}\right)$. The very high separation between $v_{1}$ and $v_{5}$ peaks $\left(204 \mathrm{~cm}^{-1}\right)$ confirms the bidentate chelation of nitrato groups. But in the nickel(II) nitrato complex the corresponding vibrations are found at 1462,1384 and $1033 \mathrm{~cm}^{-1}$. The very low separation between $v_{5}$ and $v_{1}\left(78 \mathrm{~cm}^{-1}\right)$ confirms the unidentate behaviour of nitrato groups. The bidendate chelation behaviour of sulphato group in $\mathrm{Mn}^{\prime \prime}$ and $\mathrm{Ni}^{\| 1}$ sulphato complexes is also inferred from their IR absorption bands. In the $M n^{\prime \prime}$ sulphato complex the absorptions observed at $1369,1159,1018 \mathrm{~cm}^{-1}\left(\mathrm{v}_{3}\right) ; 825\left(\mathrm{v}_{1}\right) ; 652,625,606 \mathrm{~cm}^{-1}\left(\mathrm{v}_{4}\right)$ and 526 $\mathrm{cm}^{-1}\left(\mathrm{v}_{2}\right)$ are indicative of bidentate sulphato coordination. In the $\mathrm{Ni}$ "l sulphato complex, the relevant absorptions are observed at1459,1389,1124 $\left(\mathrm{v}_{3}\right) ; 889\left(\mathrm{v}_{1}\right) ; 718,618\left(\mathrm{v}_{4}\right)$ and $484 \mathrm{~cm}^{-1}\left(\mathrm{v}_{2}\right)$ suggesting bidentate chelation of sulphato group with $\mathrm{Ni}^{l l}$ ion.

\begin{tabular}{|c|c|c|c|c|c|}
\hline Compound & $\mathrm{VOH}_{\mathrm{OH}}$ & $\mathrm{V}_{\mathrm{C}-\mathrm{N}-\mathrm{C}}$ & $v_{C-O}$ & $V_{M-O}$ & $\mathbf{V}_{\mathbf{M}-\mathrm{N}}$ \\
\hline DEBQ & 3392 & $1284-1275$ & 1093 & - & - \\
\hline $\mathrm{MnCl}_{2} \cdot \mathrm{DEBQ}$ & 3326 & $1271-1237$ & 1104 & 580 & 487 \\
\hline $\mathrm{Mn}\left(\mathrm{NO}_{3}\right)_{2} \cdot \mathrm{DEBQ}$ & 3372 & $1273-1226$ & 1092 & 599 & 450 \\
\hline $\mathrm{MnSO}_{4} . \mathrm{DEBQ}$ & 3368 & $1272-1226$ & 1103 & 606 & 526 \\
\hline $\mathrm{NiCl}_{2}$.DEBQ & 3356 & 1208 & 1100 & 550 & 471 \\
\hline $\mathrm{Ni}\left(\mathrm{NO}_{3}\right)_{2} . \mathrm{DEBQ}$ & 3383 & 1209 & 1109 & 524 & 471 \\
\hline $\mathrm{NiSO}_{4} . \mathrm{DEBQ}$ & 3326 & 1225 & 1119 & 515 & 485 \\
\hline
\end{tabular}

Table 2 IR Spectral data of DEBQ and its metal complexes $\left(\mathrm{cm}^{-1}\right)$

\section{Magnetic and electronic spectral studies}

The colours, magnetic moments and the electronic absorptions (Lever ABP,1968) of the $\mathrm{Mn}^{\prime \prime}$ and $\mathrm{Ni}^{\prime \prime}$ complexes are summarized in Table 3. $\mathrm{Mn}^{\prime \prime}$ chloro, nitrato and sulphato complexes with DEBQ are coloured red brown indicating that they may be six coordinate octahedral complexes. Generally octahedral complexes of $\mathrm{Mn}^{11}$ ion exhibit electronic absorption bands which are attributed to three spin allowed transitions ${ }^{6} A_{1 g} \rightarrow{ }^{4} T_{1 g}\left(v_{1}\right),{ }^{6} A_{1 g} \rightarrow{ }^{4} A_{1 g}+{ }^{4} E_{g}\left(v_{2}\right)$ and ${ }^{6} A_{1 g} \rightarrow{ }^{4} T_{2 g}\left(v_{3}\right)$ respectively. In the present study, the $\mathrm{Mn}^{\mathrm{II}}$ chloro, nitrato and sulphato complexes exhibit absorption bands at 13205 , 12670 and $13150 \mathrm{~cm}^{-1}$ respectively due to ${ }^{6} \mathrm{~A}_{1 \mathrm{~g}} \rightarrow{ }^{4} \mathrm{~T}_{1 \mathrm{~g}}\left(\mathrm{v}_{1}\right)$ transition. They also exhibit absorptions at 22510,22760 and $22480 \mathrm{~cm}^{-1}$ respectively due to ${ }^{6} \mathrm{~A}_{1 \mathrm{~g}} \rightarrow{ }^{4} \mathrm{~A}_{1 \mathrm{~g}}+{ }^{4} \mathrm{E}_{\mathrm{g}}\left(\mathrm{V}_{2}\right)$ transition. Absorptions of the respective complexes observed at 25220 , 25160 and $25380 \mathrm{~cm}^{-1}$ are due to ${ }^{6} \mathrm{~A}_{1 \mathrm{~g}} \rightarrow{ }^{4} \mathrm{~T}_{2 \mathrm{~g}}\left(\mathrm{~V}_{3}\right)$ transition. The Mn ${ }^{11}$ chloro, nitrato and sulphato complexes of DEBQ record magnetic moment values at 5.18, 5.25 and 5.3B.M. respectively confirming the high spin octahedral geometry. The structures of these $\mathrm{Mn}^{\mathrm{II}}$ complexes are shown in Figure 3a-c. 


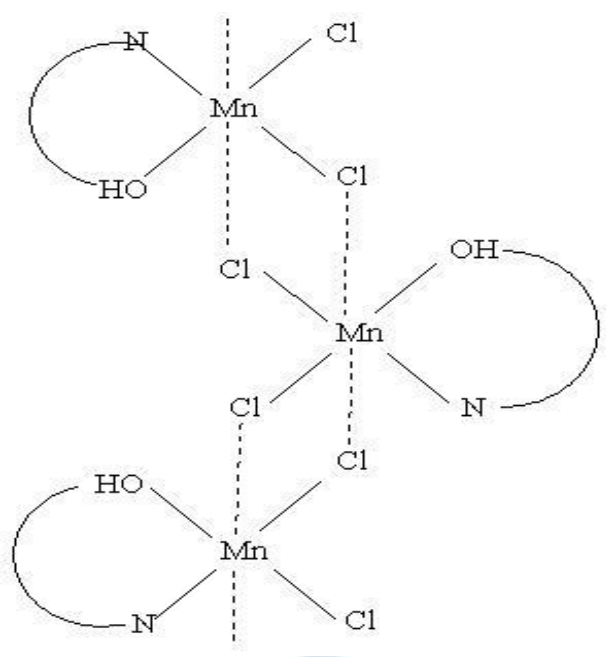

Figure 3a Structure of $\mathrm{MnCl}_{2}$.DEBQ

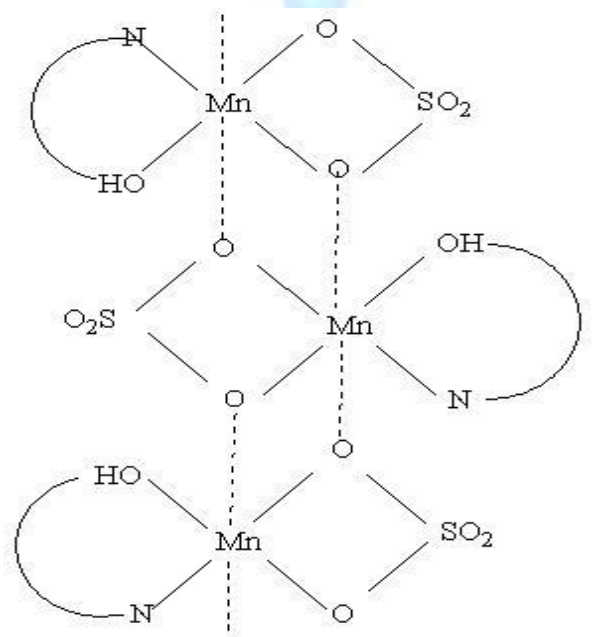

Figure 3c Structure of $\mathrm{MnSO}_{4}$.DEBQ

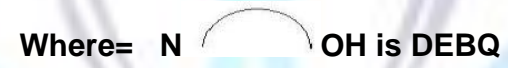

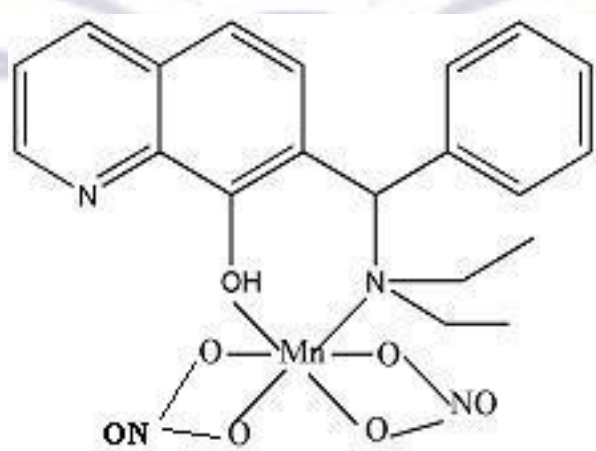

Figure $3 b$ Structure of $\mathrm{Mn}\left(\mathrm{NO}_{3}\right)_{2} \cdot \mathrm{DEBQ}$

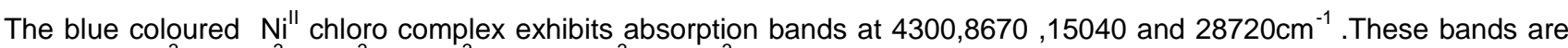
attributed to ${ }^{3} \mathrm{~T}_{1}(\mathrm{~F}) \rightarrow{ }^{3} \mathrm{~T}_{2}(\mathrm{~F}),{ }^{3} \mathrm{~T}_{1}(\mathrm{~F}) \rightarrow{ }^{3} \mathrm{~A}_{2}(\mathrm{~F})$ and ${ }^{3} \mathrm{~T}_{1}(\mathrm{~F}) \rightarrow{ }^{3} \mathrm{~T}_{1}(\mathrm{P})$ and charge transfer $(\mathrm{CT})$ transitions respectively. The $\mathrm{v}_{2} / \mathrm{v}_{1}$ ratio for the chloro complex of $\mathrm{Ni}^{\prime \prime}$ is observed at 2.016. This value is within the stipulated range 2.000-2.242 pointing to 
the tetrahedral stereochemistry for the $\mathrm{Ni}^{\text {II }}$ chloro complex. The $\mathrm{Ni}^{\text {II }}$ nitrato complex is also blue in colour and shows electronic absorption bands at $3860,8370,15100$ and $28820 \mathrm{~cm}^{-1}$ and these absorption are attributed to ${ }^{3} \mathrm{~T}_{1}(\mathrm{~F}) \rightarrow{ }^{3} \mathrm{~T}_{2}(\mathrm{~F})$, ${ }^{3} T_{1}(F) \rightarrow{ }^{3} A_{2}(F),{ }^{3} T_{1}(F) \rightarrow{ }^{3} T_{1}(P)$ and CT transitions respectively. The $v_{2} / v_{1}$, ratio for the nitrato nickel(II)complex is also with in stipulated range for the tetrahedral geometry. The $\mathrm{Ni}^{11}$ sulphato complex measures absorptions at 3990, 8720, 15207 and $28490 \mathrm{~cm}^{-1}$ which are attributed to ${ }^{3} \mathrm{~T}_{1}(\mathrm{~F}) \rightarrow{ }^{3} \mathrm{~T}_{1}(\mathrm{~F}),{ }^{3} \mathrm{~T}_{1}(\mathrm{~F}) \rightarrow{ }^{3} \mathrm{~A}_{2}(\mathrm{~F}),{ }^{3} \mathrm{~T}_{1}(\mathrm{~F}) \rightarrow{ }^{3} \mathrm{~T}_{1}(\mathrm{P})$ and CT respectively. The $v_{2} / \mathrm{v}_{1}$ ratio for this complex is measured at 2.185 which is within the stipulated range for the tetrahedral geometry. Hence the $\mathrm{Ni}^{\prime \prime}$ sulphato complex is assigned a tetrahedral geometry on the basis of the electronic spectrum.

\begin{tabular}{|c|c|c|c|c|}
\hline SI.No. & Complex & $\begin{array}{c}\text { Colour } \\
\left(\mu_{\mathrm{eff}} \text { B.M) }\right.\end{array}$ & $\begin{array}{c}\text { Absorption } \\
\text { Maxima }\left(\mathrm{cm}^{-1}\right)\end{array}$ & $\begin{array}{c}\text { Transition } \\
\text { Assignments }\end{array}$ \\
\hline 1 & $\mathrm{MnCl}_{2} . \mathrm{DEBQ}$ & $\begin{array}{l}\text { Brown } \\
(5.18)\end{array}$ & $\begin{array}{l}13205 \\
22510 \\
25220\end{array}$ & $\begin{array}{c}{ }^{6} \mathrm{~A}_{1 \mathrm{~g}} \rightarrow{ }^{4} \mathrm{~T}_{1 \mathrm{~g}} \\
{ }^{6} \mathrm{~A}_{1 \mathrm{~g}} \rightarrow{ }^{4} \mathrm{~A}_{1 \mathrm{~g}}+{ }^{4} \mathrm{E}_{\mathrm{g}} \\
{ }^{6} \mathrm{~A}_{1 \mathrm{~g}} \rightarrow{ }^{4} \mathrm{~T}_{2 \mathrm{~g}}\end{array}$ \\
\hline 2 & $\mathrm{Mn}\left(\mathrm{NO}_{3}\right) \cdot \mathrm{DEBQ}$ & $\begin{array}{l}\text { Brown } \\
(5.25)\end{array}$ & $\begin{array}{l}12670 \\
22760 \\
25160\end{array}$ & $\begin{array}{c}{ }^{6} \mathrm{~A}_{1 \mathrm{~g}} \rightarrow{ }^{4} \mathrm{~T}_{1 \mathrm{~g}} \\
{ }^{6} \mathrm{~A}_{1 \mathrm{~g}} \rightarrow{ }^{4} \mathrm{~A}_{1 \mathrm{~g}}+{ }^{4} \mathrm{E}_{\mathrm{g}} \\
{ }^{6} \mathrm{~A}_{1 \mathrm{~g}} \rightarrow{ }^{4} \mathrm{~T}_{2 \mathrm{~g}}\end{array}$ \\
\hline 3 & $\mathrm{MnSO}_{4} . \mathrm{DEBQ}$ & $\begin{array}{l}\text { Brown } \\
(5.30)\end{array}$ & $\begin{array}{l}13150 \\
22480 \\
25380\end{array}$ & $\begin{array}{c}{ }^{6} \mathrm{~A}_{1 \mathrm{~g}} \rightarrow{ }^{4} \mathrm{~T}_{1 \mathrm{~g}} \\
{ }^{6} \mathrm{~A}_{1 \mathrm{~g}} \rightarrow{ }^{4} \mathrm{~A}_{1 \mathrm{~g}}+{ }^{4} \mathrm{E}_{\mathrm{g}} \\
{ }^{6} \mathrm{~A}_{1 \mathrm{~g}} \rightarrow{ }^{4} \mathrm{~T}_{2 \mathrm{~g}}\end{array}$ \\
\hline 4 & $\mathrm{NiCl}_{2} . \mathrm{DEBQ}$ & $\begin{array}{l}\text { Blue } \\
(4.14)\end{array}$ & $\begin{array}{r}4300 \\
8670 \\
15070 \\
28720\end{array}$ & $\begin{array}{c}{ }^{3} \mathrm{~T}_{1}(\mathrm{~F}) \rightarrow{ }^{2} \mathrm{~T}_{2}(\mathrm{~F}) \\
{ }^{3} \mathrm{~T}_{1}(\mathrm{~F}) \rightarrow{ }^{2} \mathrm{~A}_{2}(\mathrm{~F}) \\
{ }^{3} \mathrm{~T}_{1}(\mathrm{~F}) \rightarrow{ }^{2} \mathrm{~T}_{1}(\mathrm{P}) \\
\mathrm{CT}\end{array}$ \\
\hline 5 & $\mathrm{Ni}\left(\mathrm{NO}_{3}\right)_{2}$. DEBQ & $\begin{array}{l}\text { Blue } \\
(4.23)\end{array}$ & $\begin{array}{r}3860 \\
8370 \\
15100 \\
28833\end{array}$ & $\begin{array}{c}{ }^{3} \mathrm{~T}_{1}(\mathrm{~F}) \rightarrow{ }^{2} \mathrm{~T}_{2}(\mathrm{~F}) \\
{ }^{3} \mathrm{~T}_{1}(\mathrm{~F}) \rightarrow{ }^{2} \mathrm{~A}_{2}(\mathrm{~F}) \\
{ }^{3} \mathrm{~T}_{1}(\mathrm{~F}) \rightarrow{ }^{2} \mathrm{~T}_{1}(\mathrm{P}) \\
\mathrm{CT}\end{array}$ \\
\hline 6 & $\mathrm{NiSO}_{4} \cdot \mathrm{DEBQ}$ & $\begin{array}{l}\text { Blue } \\
(4.19)\end{array}$ & $\begin{array}{c}3990 \\
8720 \\
15207 \\
28490\end{array}$ & $\begin{aligned} &{ }^{3} \mathrm{~T}_{1}(\mathrm{~F}) \rightarrow{ }^{2} \mathrm{~T}_{2}(\mathrm{~F}) \\
&{ }^{3} \mathrm{~T}_{1}(\mathrm{~F}) \rightarrow{ }^{2} \mathrm{~A}_{2}(\mathrm{~F}) \\
&{ }^{3} \mathrm{~T}_{1}(\mathrm{~F}) \rightarrow{ }^{2} \mathrm{~T}_{1}(\mathrm{P}) \\
& \mathrm{CT}\end{aligned}$ \\
\hline
\end{tabular}

Table-3 Colours, electronic spectral and magnetic data for $\mathrm{Mn}^{\mathrm{II}}$ and $\mathrm{Ni}$ " complexes of DEBQ

The $\mu_{\text {eff }}$ values of the chloro, nitrato and sulphato complexes of nickel are measured at 4.14, 4.23 and 4.19 B.M respectively. These values indicate a four coordinate tetrahedral geometry around the $\mathrm{Ni}^{\prime \prime}$ in these complexes.(Figure 4 )<smiles>[X]C([X])([X])N(CC)C(c1ccccc1)c1ccc2cccnc2c1O</smiles>

Figure 4 Structure of $\mathrm{Ni}^{\prime \prime}$ complexes

where $\mathrm{X}=\mathrm{Cl}, \mathrm{NO}_{3}, 0.5 \mathrm{SO}_{4}$ 


\section{Thermal decomposition studies}

\section{Thermal decomposition DEBQ}

The ligand $\mathrm{DEBQ}$ is thermally stable upto $130^{\circ} \mathrm{C}$. It undergoes a two stage decomposition in the presence of air( Kamalakannan $P$ and Venkappayya D, 2002). The first stage of decomposition is in the temperature range of $130-200^{\circ} \mathrm{C}$. This is shown by a broad DTG peak centered at $168^{\circ} \mathrm{C}$. The thermogram (Figure 5) shows the existence of an intermediate in the temperature range $200-300^{\circ} \mathrm{C}$, the composition of which is not clearly understood. The intermediate undergoes further decomposition (second stage) and complete weight loss at $300-430^{\circ} \mathrm{C}$. The decomposition of the intermediate is shown by another DTG peak centered at $363^{\circ} \mathrm{C}$. However the DTA plot is not very clear.

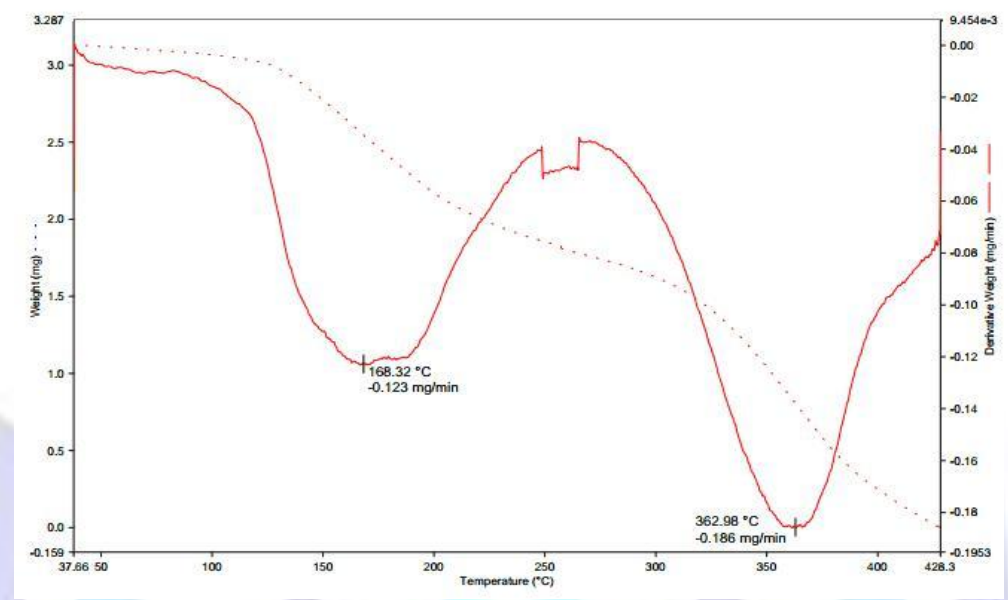

Figure 5 TG/DTG patterns of DEBQ

\section{Thermal decomposition $\mathrm{MnCl}_{2}$.DEBQ}

The thermal decomposition study on $\mathrm{MnCl}_{2}$.DEBQ shows a two stage decomposition pattern (Figure 6). The sample experiences a small initial weight loss due to elimination of adsorbed water. The onset of decomposition of the dry complex begins at $163^{\circ} \mathrm{C}$. There is a rapid weight loss of $30 \%$ in the range $163-230^{\circ} \mathrm{C}$ due to the elimination of the organic ligand (DEBQ) to form the metal chloride as the intermediate. This first stage of decomposition is indicated by the DTG peak found at $194-214^{\circ} \mathrm{C}$. The $\mathrm{MnCl}_{2}$ intermediate formed undergoes gradual decomposition in the range $475-525^{\circ} \mathrm{C}$. It is indicated by the DTG peak centered at $505^{\circ} \mathrm{C}$. The oxide of manganese is the final residue produced.The DTA peak obtained is not useful to indicate the changes involved in the thermal decomposition.
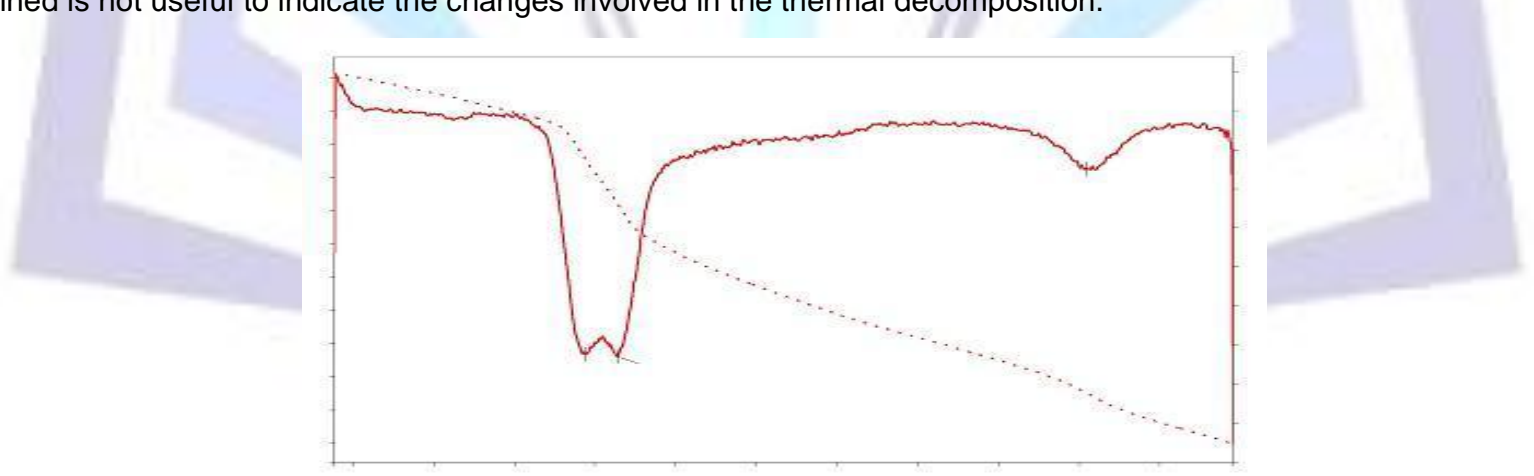

Figure 6 TG/DTG patterns of $\mathrm{MnCl}_{2}$.DEBQ

\section{Thermal decomposition $\mathrm{Ni}\left(\mathrm{NO}_{3}\right)_{2}$.DEBQ}

$\mathrm{Ni}\left(\mathrm{NO}_{3}\right)_{2}$.DEBQ also displays a two stage thermal decomposition as shown in Figure 7. The compound experiences a small weight loss in the beginning of heating due to loss of adsorbed water. The dry complex is stable upto $180{ }^{\circ} \mathrm{C}$ and it decomposes in the temperature range $180-325^{\circ} \mathrm{C}$. This first stage of decomposition involves elimination of DEBQ and the formation of $\mathrm{Ni}\left(\mathrm{NO}_{3}\right)_{2}$. as the intermediate. This decomposition is evidenced by the DTG peak centered at $245^{\circ} \mathrm{C}$. The intermediate $\mathrm{Ni}\left(\mathrm{NO}_{3}\right)_{2}$ undergoes further decomposition(second stage) to produce $\mathrm{NiO}$ as the final residue. The decomposition of $\mathrm{Ni}\left(\mathrm{NO}_{3}\right)_{2}$ to produce $\mathrm{NiO}$ is supported by the DTG peak centering at $514{ }^{0} \mathrm{C}$. The weight of the final residue is found to be at $16 \%$ of the original anhydrous complex. In this thermal decomposition study also the DTA pattern is not useful to follow the information given by TG. 


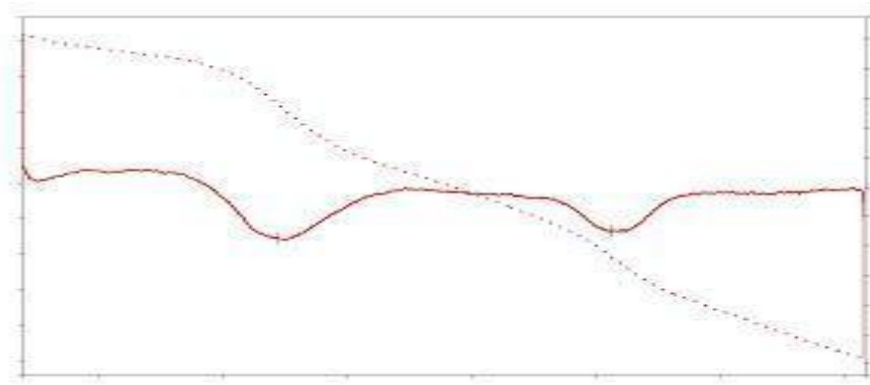

Figure $7 \mathrm{TG} / \mathrm{DTG}$ patterns of $\mathrm{Ni}\left(\mathrm{NO}_{3}\right)_{2} \cdot \mathrm{DEBQ}$

\section{Antimicrobial studies}

The Mannich base ligand (DEBQ) and its $\mathrm{Mn}^{\prime \prime}$ and $\mathrm{Ni}^{\prime \prime}$ chloro complexes have been screened for antimicrobial activity against E.coli, S.aureus, A.niger and P.chrysogenum. The levels of antimicrobial activity in terms of the zones of inhibition produced by the test compounds are presented in Table 4. The Mannich base is highly active against both the bacterial and the fungal strains tested. The Mannich base ligand exhibits comparable activity with the standard antibacterial drug used (ampicillin). But antifungal activity the Mannich base is more potent than that of standard drug (amphotericin - B). It shows that this organic compound may very well be used as an antifungal antibiotic. The mangese(II) complex exhibits more significant activity than the nickel(II) complex against both the bacterial and the fungal organisms tested.

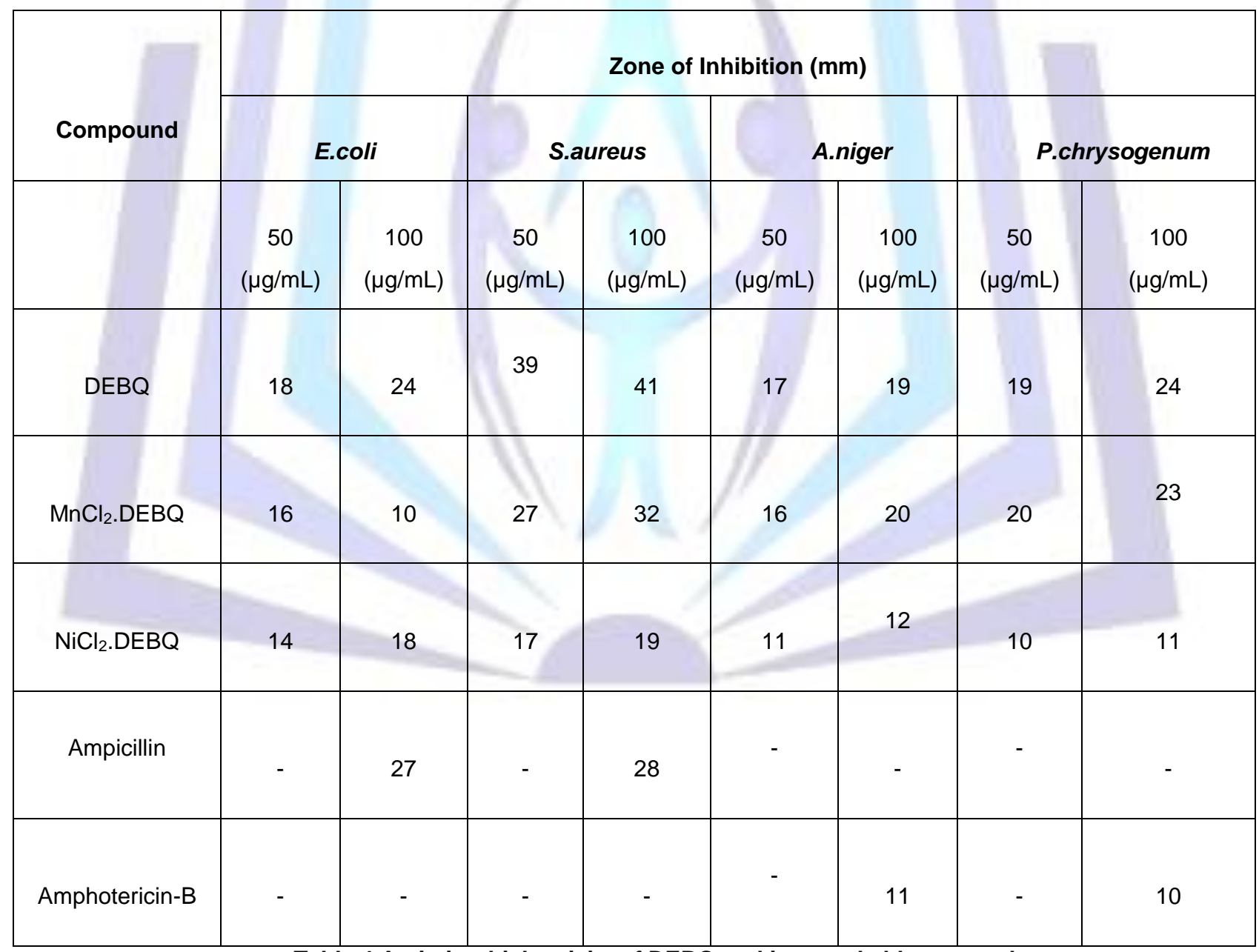

Table 4 Antimicrobial activity of DEBQ and its metal chloro complexes

\section{Conclusion}

Manganese(II) and nickel(II) ion complexes of 7-diethylaminobenzyl-8-hydroxyquinoline have been synthesized and their spectral, thermal and antimicrobial properties have been investigated. Though this ligand has several binding sites it prefers to coordinate to the metal ion through the phenolic oxygen and the diethylamino nitrogen atoms. The structures of the coordination compounds prepared have been established based on analytical and spectral data as shown in Figures 
3a-c and 4. From antimicrobial screening studies it is concluded that the Mannich base ligand is possessing more significant activity than the metal complexes as well as the standard drugs employed. Among the coordination compounds investigated manganese(II) complex is more active than nickel(II). The complexes undergo two stage thermal decomposition to form metal oxides as final residues.

\section{Acknowledgement}

The authors are the thankful to the authorities of Urumu Dhanalakshmi College, Tiruchirappalli and J.J.College of Arts and Science, Pudukkottai for providing laboratory facilities and to SAIF, IIT, Chennai for the analytical support.

\section{References}

[1] Balasubramanium, M., and Keay JG.1996.Comprehensive heterocyclic chemistryll,5:245.

[2] Bassett, J., Danney, RC., Jaffery, GH., and Hendham, J. 2000. Vogel's text Book of quantitative inorganic analysis, IV Edn, ELBS, Longman.

[3] Brain D Lee., Zhanjiang Li., Kevin J French., Yanzhaung., Zuping Xia., and Charles D .2004. J Med Chem., 47(6):1413.

[4] Cruickshankt, R.1975. A practical of medicinal microbiology, Churchill Livingstone, Edenburg, 2.

[5] Ferraro, JR. 1971. Low frequency vibrations of inorganic and coordination compounds, Plenum Press, New York.

[6] Geary WJ. 1971. Coord.Chem.Rev, 7:81.

[7] Guytan, AC., and Hall JE. 1998.Textbook of medicinal physiology IX Edition Singapore,P,AWB Sanders Company,306

[8] Kamalakannan, P., and Venkappayya, D. .2002. Russian J Coord Chem., 28:423.

[9] Lever ABP. 1968. Inorganic electronic spectroscopy, Elsevier, Amsterdam.

[10] Maguire, M.P., Sheets, KR., Mcvety K,Spanda, AP., and Ziberstein, AJ. 1994. J Med Chem, 37(4):2129.

[11] Meth-Cohn, O., Narine, B., and Tarnowski, B. 1981. J Chem Soc Perkin Trans,306.

[12] Micheal, J.P. 1997. Nat Prod Rep,14:605.

[13] Muthukumar, C., Sabastiyan, A., Ramesh, M., Subramanian, M., and Yosuva Suvaikin, M. 2012., 4(4):1322.

[14] Muthukumar, C., Valarselvan, S., Sabastiyan, A., and Yosuva Suvaikin, M. .2013. Che Sci Rev Lett-accepted.

[15] Nakamoto, K. 1978. Infrared and Raman spectra of inorganic and coordination compounds, III Edn, Wiley Interscience, New York.

[16] Pandey, VK., and Menal Tondan. 2001. Indian J Chem,40B:527.

[17] Ramesh, M., and Sabastiyan, A. 2012. Der Chemica Sinica, 3(3):534.

[18] Rao, A., Carbone, A., Chimirri, A., De Clercq.p.Monforte,Pietro,Pannecougue C and Zoppala M.2002, Farmaco,57(9):747.

[19] Sabastiyan, A., and Yosuva Suvaikin, M. 2012. Advances in Applied Research, 3(1): 45.

[20] Sathya, D., Senthilkumaran, J., Jayachandramani, N., and Amali Roselin Emelda. 2012. Research Journal of Pharmaceutical, Biological and Chemical Sciences, 3(2):905.

[21] Silverstein, RM., and Webster, FX. 1997. Spectrometric identification of organic compounds, IV Edn, John wiley \& Sons, Inc, New York.

[22] Singh, OMV., and Muthukrishnan, M. 2001.Indian J Chem.., 40B:262.

[23] Tamilvendan, D., Rajeswari, S., Illavenil, S., and Venkatesa Prabhu. G. 2010. Orbital Elec.J.Chem Compo Grande, 2:10.

[24] Tromontini, M., and Angiolini, L. 1994. Mannich bases-chemistry and uses, CRC Press, Inc, U.S.A.

[25] Tromontini, M., 1973. Synthesis., 7023.

[26] Vetrivel Nadaraj, Senniappan Thamaraj Selvi, and Raju Sasi. 2006. Arkivoc,10:82.

[27] Yosuva Suvaikin, M., and Sabastiyan, A. 2012. International Chem Tech Research;4(2):805.

[28] Yuki Sowada, Hiroshi Kayakiri, Yoshito Abe and Hirokazu Tanaka. 2004. J Med Chem,47:2853. 